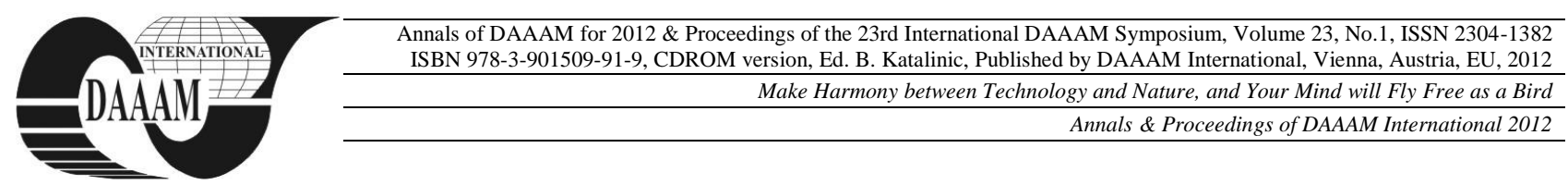

\title{
TOTAL FACTOR PRODUCTIVITY IN CROATIAN COMPUTER INDUSTRY
}

\author{
HERCEG, T[omislav]; JAKOVIC, B[ozidar] \& RKMAN, P[etra]
}

\begin{abstract}
The aim of this paper is to present the current state of the Croatian computer industry with a brief historical overview and to show the ways how to improve it using the microeconomic analytical tools. After estimating the production function for computer industry in Croatia, it is shown that due to the decreasing returns to scale this sector should rise through the rise of the total factor productivity. Estimating the TFP model for Croatian computer industry, it is sown that the export orientation of the company increases its TFP. It is also proven that computer industry's TFP rises as the number of the companies in this sector rises which confirms that competitiveness improves productivity.
\end{abstract}

Keywords: total factor productivity/ Cobb-Douglas production function/computer industry/export oriented industries

\section{INTRODUCTION}

The computer and information technology industries are multi-faceted with many interrelationships. The global computer industry is both complicated and very dynamic. As such, it is extremely problematic to make specific predictions for the next five to ten years. The combination of Mainland China and the Overseas Chinese from Taiwan, Singapore and those who have worked for high technology companies in the United States could become an even more powerful force in the global computer industry of the future [1].

Despite the fact that age discrimination is a common issue in many industries, the computer industry is reputed to be one of the most ageist industries. A 1997 breakdown by age of college graduates in the U.S. work force shows that $37 \%$ of these workers were 45 and older. But among computer scientists and programmers, only $23 \%$ were 45 and older. The numbers are even more striking in the over-55 age group, which constituted $12 \%$ of the total college-educated U.S. work force but only $5 \%$ of the IT field. Even if women are moving up in IT management ranks, they are not reaching the upper level as fast as they are in other industries. Only $29 \%$ of 500 female executives surveyed by the Women in Technology International business group in Sherman Oaks, California believe they have the same chance as their male colleagues of becoming CEOs for their present employers. The computer industry is a new and fastgrowing industry. People who work in this industry have to update their skills and knowledge constantly in order to keep abreast with the rapidly new technology development. This accounts for the fact the industry prefers to hire the 20s, who are perceived to be young, energetic with great potential. Most of them have good training and are open to new technologies, especially those who are freshly out of school and know the latest computer languages. Conversely, older workers are seen as dinosaurs. There are stereotypes that older workers do not want to or cannot learn new technologies.

They lack the latest skills, are slow and are reluctant to learn new skills. They present a cultural mismatch in the youth-oriented computer field and cannot fit into the fast-paced environment. Software companies and Internet start-ups, in particular, tend to be founded and run by young people who are simply more comfortable working with their peers. Companies do not want to hire older workers for entry-level jobs because they do not want a 40 -year-old reporting to a young manager who might be around 25 years old. As a fact of life, young managers may hesitate to give orders to older employees, as older people will not like being told what to do by someone younger. Some influential organisations in the computer industry, such as the Computing Services and Software Association, the IT Industry Training Organisations have spoken out against the view that older people are inflexible, slow to take on new technology, want too much money and lack energy and ambition [2].

Computer technology is pervasive in modern society, and the computer and its peripheral industry is vital to economic progress. However, the global competition continues to escalate, particularly in the computer industry. Scare resources, fierce global competition and rapid technological advancement in the computer industry require continuous improvement in quality [3].

The speed at which companies can introduce new products into the market has become crucial for those who want to sustain a competitive advantage and a higher market share. The emphasis on rapid product development is due to finding that the largest market share is attained by the firm that first introduces the product to the market. Studying the impact of time-based product development on market share gains in a hightech computer components industry, researchers concluded that lead-time advantage does affect market share positively, although with a different intensity at each stage of the development process (concept generation, prototype completion, volume production). Rosas-Vega \& Vokurka in their paper detect the reasons for delaying the introduction of new products into the market. Analysis of the data showed that 79 percent of the reasons for delay were due to internal problems (under the control of the organization). Technical problems, such as bugs, incomplete core features, long testing and changes during the development cycle accounted for approximately 80 percent of the internal reasons. Only 21 percent of the total set of reasons was related to external factors not under the direct control of 
the companies. In this category, problems with third parties had the highest frequency [4].

Hornby \& Macleod aims to identify the main pricing objectives of firms in the Scottish computer industry and relate these to: financial performance, the nature of the competition, the size, and the different stages of market evolution. The industry as a whole provides a significant

Proportion of the UK's wealth and thus the basis on which prices are set should be the subject of investigation. The industry comprises both manufacturing and service firms giving a balanced representation of a pricing behaviour between two different sectors. Analysing the industry on a geographical basis is also important since Scotland's market is unique and not necessarily affected by cyclical downturns in the UK.

Looking at a single industry is also important, since the economic environment and external market factors faced by firms in the industry are similar, thus any differences emerging will be predominantly due to "internal" factors rather than "external" market-driven factors.

The computer industry represents around 5 per cent of the UK economy. The long-term trend is for computing to grow in importance, although current recession has kept the computer industry's growth in line with GNP growth. By the end of the century, computing could account for around 7 per cent of the UK's GNP.

The significance of the computer industry should not be judged by its share of GNP alone: computers increase productivity which in turn enhance. Most firms within the Scottish computer industry have some form of control over prices and the majority cited profit maximization as the principal pricing objective. This result seems to give some support to the traditional neoclassical theory of profit maximization.

Of the 45 per cent that claimed to be pursuing maximum profits, however, only about 4 per cent satisfy the conditions necessary and sufficient for them to be regarded as true profit maximizers. The majority of firms, therefore, would appear to be acting as satisfiers. [5].

Nanotechnology, biology and genomics are the areas which see the greatest investment today and hold the greatest opportunities for dramatic growth and societal and economic impact in the coming years. Technology continues to rapidly evolve and grow - just in different directions and with different industries [6].

The growing concern for the environment, coupled with rapid increase in the introduction and use of new technology in the marketplace, has led to increased interest and focus in reverse logistics. The study of reverse logistics in the computer industry is important to the Asia Pacific region including Singapore. Computer companies are more willing to give higher trade-in value for computers with more recent technologies than those with older technologies [7].

\section{COMPUTER INDUSTRY IN CROATIA}

Although Croatia has the quality computer engineers, highly valued informatics and electronics faculties and companies which could manufacture this kind of products, Croatian computer manufacturing account for only $2,15 \%$ of the total manufacturing in Croatia and $0,35 \%$ of the Croatian gross domestic product (calculation based upon the FINA data). Although computer industry has exponential growth in the last two decades, Croatian computer industry had a negative growth trend in the same period. The reason for it is the fact that Croatia had a significant pocket calculator industry in Buje, Digitron, which was well known even beyond the ex Yugoslavian borders. Unfortunately, it was privatized in a typical transitional privatization process in which the company was brought to its knees and eventually went bankrupt, along with many other small businesses which were selling intermediate goods to Digitron.

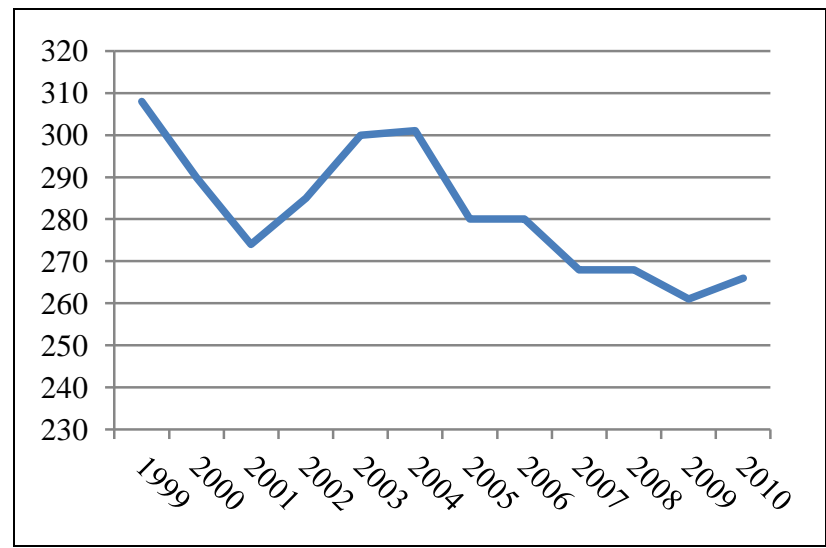

Fig. 1. Number of the computer producing companies in Croatia from $1999-2010$

The negative trend in the number of the computer production companies is shown in the diagram in the Figure 1. Unfortunately the decline in the number of computer producing companies was not the matter of the stronger companies crowding out the weaker ones, but the decline of this whole branch of the manufacturing in Croatia. It resulted in the decline in the number of workers in the computer production as well. In the Figure 2 it can be seen that by the end of the 2000 the number of workers in computer industry was near 4000 , but it had a sharp decline in 2001 and 2002 and now is stable between 1500 and 2000 workers, with mildly negative trend.

Today the leading role in this industry has Končar which made a few models of laptops in the last decade. However, the last crisis has had a detrimental effect on this industry. Due to the immense benefits of this clean industry which uses highly skilled labour and produces expensive products, the state should implement the measures which would improve the current state of this industry.

The world market of computer manufacturers is highly concentrated; there are two producers of the computer processors, Intel and AMD, only a few producers of the hard drives, the best known laptop assemblers are Toshiba, Acer, Lenovo and Apple, and in the pocket calculator industry more than $90 \%$ of the world market is covered by Casio, Sharp and Texas Instruments. Hence Croatian manufacturers should take into account that their market niche computer assembling and intermediate goods production. 


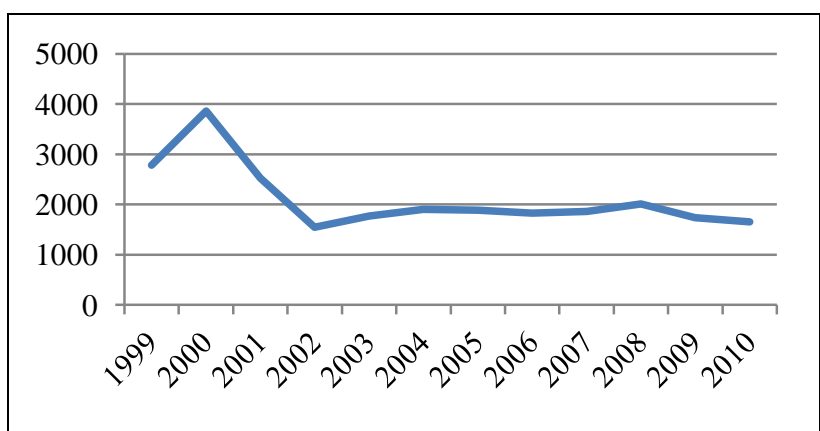

Fig. 2. Number of workers in the computer producing companies in Croatia from 1999 - 2010

\section{PRODUCTION FUNCTION IN CROATIAN COMPUTER INDUSTRY}

In order to investigate the technology of the Croatian computer industry, a microeconomic approach is going to be applied. In this approach a production function will be estimated using econometric procedures for the parameters estimation [8] and the data obtained from FINA (Croatian Financial Agency).

The most applied function for the production function estimation is the Cobb-Douglas function [9],[10]. Its general form is

$$
Y=A K^{\kappa} L^{\lambda}
$$

The linearized model is:

$$
\ln Y=\beta_{0}+\beta_{1} \ln K+\beta_{2} \ln L+u_{t}
$$

The data for the analysis is the time series with quarterly data from 1999 - 2010 (48 observations). Due to the seasonal character three dummy variables are introduced. Then the model looks as follows:

$$
\ln Y=\beta_{0}+\beta_{1} \ln K+\beta_{2} \ln L+\delta_{1} \mathrm{r}_{1}+\delta_{2} \mathrm{r}_{2}+\delta_{3} \mathrm{r}_{3}+u_{t}
$$

The estimation results show that in this form the model is not adequate. Hence the initial function (1) is transformed into (4)

$$
Y=A(K L)^{\kappa}
$$

The model for the production function parameters estimation is now equal to (3), but $\beta_{1}=\beta_{2}$. This model appears to be adequate (no autocorrelation, all parameters are significant at the level $\alpha<0.005$ and the $F$ value is high. The $\mathrm{R}^{2}$ is near 0.70 . Then the production function is:

$$
\widehat{Y}=e^{12.8886+0.0424 r_{1}+0.0425 r_{2}+0.425 r_{3}}(K L)^{0.2368}
$$

The production elasticity shows that the returns to labour and capital, as well as the returns to scale, are decreasing. Hence the main channel of the impact should be the TFP.

\section{TOTAL FACTOR PRODUCTIVITY IN CROATIAN COMPUTER INDUSTRY}

TFP is calculated as the residual of the production function [11]. It is often denoted as A, but some authors decompose it to include trend and season dummies [12]. In the simplest form the TFP is the constant of the production function and the disturbance term [13]. In any of these cases this assumption should be expressed in the form of the production function estimation model. Afterwards TFP will be calculated according to the expression (6) [14].

\begin{tabular}{|c|c|c|c|c|c|}
\hline quarter & $\mathbf{A}_{\mathbf{1 9 9 9 . 4} \text {-100 }}$ & quarter & $\mathbf{A}_{\mathbf{1 9 9 9 . 4}=100}$ & quarter & $\mathbf{A}_{\mathbf{1 9 9 9 . 4}=100}$ \\
\hline $\mathbf{1 9 9 9 . 4}$ & 100,0 & $\mathbf{2 0 0 3 . 3}$ & 180,8 & $\mathbf{2 0 0 7 . 2}$ & 226,7 \\
\hline $\mathbf{2 0 0 0 . 1}$ & 101,8 & $\mathbf{2 0 0 3 . 4}$ & 187,5 & $\mathbf{2 0 0 7 . 3}$ & 226,8 \\
\hline $\mathbf{2 0 0 0 . 2}$ & 108,6 & $\mathbf{2 0 0 4 . 1}$ & 188,7 & $\mathbf{2 0 0 7 . 4}$ & 227,0 \\
\hline $\mathbf{2 0 0 0 . 3}$ & 114,8 & $\mathbf{2 0 0 4 . 2}$ & 190,6 & $\mathbf{2 0 0 8 . 1}$ & 227,5 \\
\hline $\mathbf{2 0 0 0 . 4}$ & 123,1 & $\mathbf{2 0 0 4 . 3}$ & 192,5 & $\mathbf{2 0 0 8 . 2}$ & 227,6 \\
\hline $\mathbf{2 0 0 1 . 1}$ & 125,9 & $\mathbf{2 0 0 4 . 4}$ & 192,4 & $\mathbf{2 0 0 8 . 3}$ & 228,1 \\
\hline $\mathbf{2 0 0 1 . 2}$ & 130,8 & $\mathbf{2 0 0 5 . 1}$ & 191,6 & $\mathbf{2 0 0 8 . 4}$ & 229,1 \\
\hline $\mathbf{2 0 0 1 . 3}$ & 138,9 & $\mathbf{2 0 0 5 . 2}$ & 189,4 & $\mathbf{2 0 0 9 . 1}$ & 225,2 \\
\hline $\mathbf{2 0 0 1 . 4}$ & 151,6 & $\mathbf{2 0 0 5 . 3}$ & 188,1 & $\mathbf{2 0 0 9 . 2}$ & 219,2 \\
\hline $\mathbf{2 0 0 2 . 1}$ & 150,1 & $\mathbf{2 0 0 5 . 4}$ & 194,3 & $\mathbf{2 0 0 9 . 3}$ & 210,8 \\
\hline $\mathbf{2 0 0 2 . 2}$ & 145,9 & $\mathbf{2 0 0 6 . 1}$ & 197,2 & $\mathbf{2 0 0 9 . 4}$ & 196,3 \\
\hline $\mathbf{2 0 0 2 . 3}$ & 143,2 & $\mathbf{2 0 0 6 . 2}$ & 203,4 & $\mathbf{2 0 1 0 . 1}$ & 195,6 \\
\hline $\mathbf{2 0 0 2 . 4}$ & 152,3 & $\mathbf{2 0 0 6 . 3}$ & 212,9 & $\mathbf{2 0 1 0 . 2}$ & 195,4 \\
\hline $\mathbf{2 0 0 3 . 1}$ & 156,6 & $\mathbf{2 0 0 6 . 4}$ & 222,3 & $\mathbf{2 0 1 0 . 3}$ & 195,9 \\
\hline $\mathbf{2 0 0 3 . 2}$ & 167,1 & $\mathbf{2 0 0 7 . 1}$ & 224,7 & $\mathbf{2 0 1 0 . 4}$ & 196,9 \\
\hline
\end{tabular}

Tab. 1. Total factor productivity in the Croatian computer industry base indices $(1999.4=100)($ MA)

$$
A=\frac{Y}{(K L)^{\kappa}}
$$

Using the expression (6) the total factor productivity for Croatian computer industry is calculated. The base indices (4th quarter $1999=100$ ) are expressed in the Table 1. The diagram in the Figure 3 shows the TFP in computer industry in Croatia in the past decade. It can be seen that it had a dynamic rise from 1999 until the beginning of the crisis and reached $229 \%$ of what it was in the 1999. However, due to the recession, it fell down to $197 \%$ in 2010 , which is almost double than eleven years before that.

There may be several reasons for that. One can be the decline of the exporting markets [15], or the unfavourable exchange rate [16], decline in the wages in the most significant export markets [17], etc. The thorough analysis of the cause for the TFP change is made in the following paragraph.

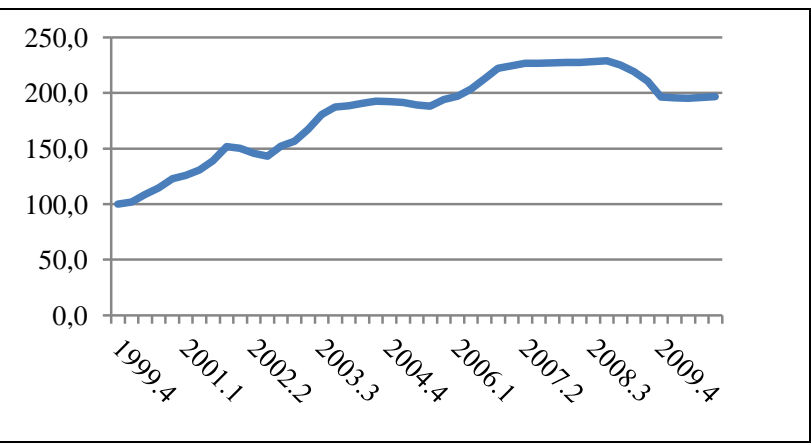

Fig. 3.Total factor productivity in the Croatian computer industry - base indices $(1999.4=100)(\mathrm{MA})$ 


\section{TOTAL FACTOR PRODUCTIVITY MODEL}

Total factor productivity has been the most dynamic power for the growth of the computer industry in Croatia in the last decade, since the technical coefficients of the production function show that doubling capital and labour yields less than double computer production. Hence it is crucial to understand the formation of the TFP and recognize the factors that affect it.

Capital and labour are called the basic production factors. TFP, being the residual, is affected by the indirect production factors. Unlike the basic factors which are well known, the indirect factors are not that obvious and well-known. Therefore they should be surveyed for every particular industry separately.

Many studies that decompose TFP use the variety of variables to show which of them affect TFP growth. The most common indirect production factors are research and development investment [18], exchange rates [16], inflation rate [20], interest rate [21], profits [22], export orientation [15], etc. Numerous models have been tested, but only the following appeared to be adequate:

$$
Y=\beta_{1} B P+\beta_{2} E X+u
$$

The estimated model is

$$
Y=\underset{(0.0000)}{0.699931 B P}+0.00000102 E X
$$

An increase in the number of the computer producing companies by 1 increases the total factor productivity of the computer industry by $0,7 \%$ (on average). The increase in the amount of exports of computer industry products by HRK Mill. 1 increases the TFP of the computer industry by 1,02\%, on average.

\section{CONCLUSION}

Although computer industry is a desirable, clean industry with high revenues, it accounts for only $0,35 \%$ of Croatian GDP. In order to make a thorough analysis of this industry, a microeconomic approach was used. First, a production function parameters were estimated, assuming Cobb-Douglas production function. It is shown that in this industry exist diseconomies of scale. However, decreasing returns to scale could be overcome if the TFP rose. Analyzing the TFP trend it is shown that in the last decade TFP was doubled. In order to investigate the ways to improve the TFP even more, a TFP model was formed. The analysis has shown that the greater the market competition, the greater TFP. Also, it is shown that the more this production sector exports, the greater is its TFP. Hence the government should encourage the entrance of the new companies in the computer industry, as well as to promote this sector's export orientation through subsidies.

\section{REFERENCES}

[1] Bridwell, L. \& Kuo, C-J. (2005). An analysis of the computer industry in China and Taiwan using Michael Porter's determinants of national competitive advantage, Competitiveness Review: An International Business Journal incorporating Journal of Global Competitiveness, Vol. 15 Iss: 2 pp. $116-120$

[2] Xia, A. \& Kleiner, B. H. (2001). Discrimination in the computer industry, Equal Opportunities International, Vol. 20 Iss: 5 pp. 117 $-120$

[3] Su, C-T.; Chen, M-C. \& Cheng, G-C. (2001). TQM in Taiwan's computer and its peripheral industry, Industrial Management \& Data Systems, Vol. 101 Iss: 7 pp. $357-362$

[4] Rosas-Vega, R. \& Vokurka, R. J. (2000). New product introduction delays in the computer industry, Industrial Management \& Data Systems, Vol. 100 Iss: 4 pp. 157 - 163

[5] Hornby, W. B. \& Macleod, M. (1996). Pricing behaviour in the Scottish computer industry, Management Decision, Vol. 34 Iss: 6 pp. $31-42$

[6] Herther, N. K. (2003). Today's computer industry: facing major challenges, The Electronic Library, Vol. 21 Iss: 3 pp. $262-265$

[7] Kwan Tan, A. W. \& Kumar, A. (2006). A decision-making model for reverse logistics in the computer industry, The International Journal of Logistics Management, Vol. 17 Iss: 3 pp. 331 - 354

[8] Bahovec, V. i N. Erjavec (2009). Uvod u ekonometrijsku analizu, Element, Zagreb

[9] Beeson, P. 1987. Total Factor Productivity Growth And Agglomeration Economies In Manufacturing, 1959-73. Journal of Regional Science, Vol. 27, Issue 2 (May), pp 183-199

[10] Aw, B.Y., X. Chen, M. J. Roberts. 2001. Firm-level evidence on productivity differentials and turnover in Taiwanese manufacturing. Journal of Development Economics, Vol. 66 , p. 51-86

[11] Miller, S. M., M. P. Upadhyay. 2002. Total factor productivity and the convergence hypothesis. Journal of Macroeconomics Vol. 24, p. 267-286

[12] Nadiri, M. I. 1970. Some Approaches to the Theory and Measurement of Total Factor Productivity: A Survey. Journal of Economic Literature, Vol. 8, No. 4 (Dec.), pp. 1137-1177

[13] Nehru, V., A. Dhareshwar. 1994. New Estimates of Total Factor Productivity Growth for Developing and Industrial Countries. Policy Research WP 1313 (June)

[14] Weber, W. L., B. R. Domazlicky. 1999. Total factor productivity growth in manufacturing: a regional approach using linear programming. Regional Science and Urban Economics Vol. 29, p. $105-122$

[15] Nishimizu, M., JM. Page, Jr 1982. Total Factor Productivity Growth, Technological Progress and Technical Efficiency Change: Dimensions of Productivity Change in Yugoslavia, 196578. The Economic Journal, Vol. 92, No. 368 (Dec), pp. 920-936

[16] Wen, G. J. 1993. Total Factor Productivity Change in China's Farming Sector: 1952-1989. Economic Development and Cultural Change, Vol. 42, No. 1 (Oct.), pp. 1-41

[17] Palmero, A., J. H.. 2004. Total Factor Productivity and Growth in Mexican Manufacturing During the Period 1929. - 1944. University of California, Los Angeles

[18] Van Beveren, I. 2007. Total Factor Productivity Estimation: a Practical Review. LICOS Discussion Paper No. 182/2007

[19] Prescott, E. C. 1999. L. R. Klein Lecture 1997: A Theory of Total Factor Productivity. International Economic Review, Vol. 39, No. 3 (Aug., 1998), pp. 525-551

[20] R.L. Moomaw, R.L., M. Williams. 1991. Total Factor Productivity Growth In Manufacturing Further Evidence From The States. Journal of Regional Science, Vol. 31, Issue 1 (Feb), pages 17-34

[21] Virmani, A. 2004. Sources Of India's Economic Growth: Trends In Total Factor Productivity. ICRIER Working Paper No. 131 (May)

[22] Wong, F.C., W.B. Gan. 1994. Total factor productivity growth in the Singapore manufacturing industries during the 1980's. Journal of Asian Economics, Vol. 5, Issue 2, pp. 177-196 